\title{
PERJUANGAN AGRARIA DI KECAMATAN JENGGAWAH KABUPATEN JEMBER: SUATU BENTUK PERLAWANAN SIMBOLIK TAHUN 1998-2005
}

\section{AGRARIAN STRUGGLE IN JENGGA WAH-JEMBER: A SYMBOLIC STRUGGLE IN 1998-2005}

\author{
Mohamad Il Badri, Yety Rochwulaningsih, dan Alamsyah \\ Alumnus pada Program Studi Magister Ilmu Sejarah, FIB Universitas Diponegoro \\ il.badri@yahoo.com,wulan.psa.undip@gmail.com, alam_mahir@yahoo.com
}

\begin{abstract}
This paper aims to understand the change of the farmers' struggle movement from physical into symbolic in a region namely Jenggawah which is located in Jember Regency in 1998-2005. The struggles of the farmers are divided into physical and symbolic struggle. The way of the struggle has changed since 1998. The farmers' symbolic struggle was conducted through some exhortation and insistence in the form of statement letter for the government or related institution concerning about the land status. Symbolic struggle is an unseen struggle and it can only be recognized through its aim in order to get acknowledgement from other group. The mechanism of this struggle movement tends to be smooth. It is expressed in the form of scientific discourse in written text. The factors that change the movement are the change of political system from New Order Regime into Reformation Era in 1998 and HGU release. The legality of land owning, in the end of this long symbolic struggle, was noted by the gradually launching of land certificates in 2001 from BPN Jember for the farmers.
\end{abstract}

Keywords: agarian struggle, forms, farmers' symbolic struggle

\section{Abstrak}

Tulisan ini bertujuan untuk mengetahui perubahan perjuangan agraria di Kecamatan Jenggawah Kabupaten Jember yang merupakan suatu bentuk perlawanan simbolik petani pada tahun 1998-2005. Perlawanan petani Jenggawah terdiri dari dua bentuk, yaitu perlawanan fisik dan perlawanan simbolik. Seiring dengan berjalannya waktu, pola perlawanan petani Jenggawah mengalami perubahan sejak tahun 1998. Perlawanan simbolik petani Jenggawah dilakukan melalui desakan dan paksaan dengan surat pernyataan sikap kepada pemerintah atau lembaga yang terkait mengenai status tanah yang diperjuangkan. Perlawanan simbolik adalah perlawanan tidak tampak dan hanya dikenali dari tujuannya untuk memperoleh pengakuan terhadap kelompok lain. Mekanisme perlawanan simbolik berlangsung secara lembut diekpresikan dalam bentuk wacana ilmiah dalam teks tertulis. Faktor perubahan gerakan dari perlawanan fisik menjadi perlawanan simbolik disebabkan oleh pergantian pemerintahan dari Orde Baru ke Orde Reformasi pada tahun 1998 dan adanya pelepasan tanah HGU untuk diberikan kepada petani. Legalitas pemilikan tanah di akhir perlawanan simbolik ditandai dengan pemberian sertifikat tanah pada tahun 2001 kepada petani Jenggawah oleh BPN Jember secara bertahap.

Kata kunci: perjuangan agraria, bentuk perlawanan simbolik petani

\section{Pengantar}

Konflik agraria di Indonesia antara petani dan pemerintah diwarnai dengan tindakan kekerasan sebagai bentuk protes ketidakadilan. Salah satu contoh konflik tersebut adalah konflik antara petani dan pemerintah yang terjadi di Jenggawah. Petani Jenggawah adalah masyarakat yang bercorak agraris perkebunan dan tanah merupakan harta yang sangat berharga karena tanah merupakan tempat untuk memproduksi berbagai macam kebutuhan pokok untuk mencukupi kebutuhan hidup (Badri, 2016: 29). Bagi petani Jenggawah, tanah memiliki makna yang multidimensi. Pertama, dari segi ekonomi, tanah merupakan sarana produksi yang dapat mendatangkan kesejahteraan. Kedua, secara politis, tanah juga bisa menentukan posisi seseorang dalam pengambilan keputusan masyarakat. Ketiga, dari segi budaya, tanah dapat menentukan tinggi rendahnya status sosial pemiliknya. Dengan adanya makna-makna tersebut, tidak heran jika petani Jenggawah berupaya mempertahankan tanah dengan berbagai cara, meskipun resiko yang akan diterima cukup besar. Hal tersebut dapat dilihat dari sikap dan tindakan petani Jenggawah dalam mempertahankan tanah mereka (Wiradi, 2000: 12). 
Konflik tanah Jenggawah bermula pada tahun 1969 dan terjadi setelah tersiar kabar ada pergantian girik atau pethok D menjadi sertifikat pada tahun 1969 yang dilakukan oleh aparat desa, kecamatan, dan beberapa aparat keamanan. Petani yang tidak mengumpulkan pethok tanah diancam akan dikenai hukuman penjara oleh pihak Koramil dan Kepolisian setempat. Selain ancaman penjara, pihak Koramil dan Kepolisian yang bekerjasama dengan PTP XXVII memberikan stigma kepada petani jika tidak menyerahkan pethok tanah dicap sebagai kelompok Partai Komunis Indonesia (PKI) yang membangkang terhadap pembangunan pemerintah (Achmad. 2007: 62-63, Mata Najwa: 2010). Pola penguasaan, pemanfaatan, dan pengelolaan sumber daya alam tersebut memperlihatkan kecenderungan hubungan asimetris yang melibatkan aktor negara dan korporasi, yang dihadapkan secara langsung dan terbuka dengan masyarakat. Negara cenderung memberi ruang terbuka bagi kepentingan perusahaan besar tanpa mempertimbangkan kepentingan rakyat. Seperti halnya kasus tanah di Jenggawah, pemerintah lebih cenderung memberi ruang terbuka kepada PTP XXVII untuk tetap mengelola tanah demi kelangsungan tanaman perkebunan (Syafi'i. 2016: 415). Sejak saat itu, petani menyerahkan girik atau pethok $\mathrm{D}$ kepada pemerintah setempat. Namun, diketahui pada tahun 1979, girik atau pethok $\mathrm{D}$ petani itu ternyata dijadikan lampiran permohonan HGU oleh PTP XXVII kepada Menteri Dalam Negeri (Hafid, 2001: 55). Atas nama hak menguasai dari negara, kemudian pemerintah melakukan klaim atau pemanfaatan baru bagi badan-badan usaha seperti PTP XXVII (Setiawan, 2010: 355-356). Pascapengajuan HGU, PTP XXVII mendapatkan SK Menteri Dalam Negeri nomor 32/HGB/BA/1969 tanggal 15 Desember 1969. SK tersebut berisi HGU kepada PTP XXVII dengan masa berlaku selama 25 tahun dan berakhir pada tanggal 22 Mei 1994. Luas areal yang termasuk dalam SK ini berkisar 2.080,7578 ha (Menteri Dalam Negeri: 1969). Penyalahgunaan data tersebut melahirkan kemarahan petani dengan melakukan perusakan berbagai infrastruktur milik pemerintah dan PTP XXVII pada tahun 1979, 1994, dan 1995.

Manipulasi data lahan oleh pihak PTP XXVII memicu terjadinya tindakan kekerasan dan kerusuhan besar pada bulan Januari sampai Juli tahun 1979. Petani Jenggawah melakukan tindakan perusakan fisik, seperti pembakaran gudang serta perusakan rumah dan tanaman milik
PTP XXVII. Kejadian tersebut menyebabkan terjadinya penangkapan wakil petani oleh aparat keamanan dengan tuduhan melakukan perusakan. Setelah penangkapan itu, petani bersepakat untuk menunggu berakhirnya HGU tahun 1994 dan 1995.

Konflik kedua terjadi pada tahun 19941995 yang disebabkan oleh keputusan BPN nomor 74/HGU/BPN/1994 dan nomor 117/HGU/1995 tentang perpanjangan HGU kepada PTP XXVII berlaku sampai tahun 2019 dan 2020. Lahirnya keputusan tersebut kembali menimbulkan konflik yang hampir sama dengan kejadian tahun 1979. Pada konflik kedua ini petani, Jenggawah berhasil menguasai dan menduduki tanah (Harian Surya, 1994: 13).

Konflik di Jenggawah melibatkan 4 kelompok, yaitu: petani dengan pemerintah, petani dengan Perseroan Terbatas Perkebunan (PTP) XXVII, petani dengan petani, dan Pemerintah Pusat dengan Pemerintah Daerah. Oleh karena itu, konflik agraria di Jenggawah berlangsung secara luas dan bersifat kompleks. Konflik antara petani dengan PTP XXVII yang didukung oleh pemerintah muncul karena adanya perbedaan kepentingan. Di satu sisi, PTP XXVII dan pemerintah mempunyai kepentingan untuk tetap menguasai tanah demi berlangsungnya budi daya penanaman tembakau jenis Na-Oogst. Di sisi lain, petani beranggapan bahwa tanah yang selama ini dikuasai pihak PTP XXVII sangat merugikan, karena terjadi penyalahgunaan data tanah. Persinggungan antara Pemerintah Daerah dengan Pemerintah Pusat terjadi karena ketidaksinkronan koordinasi sehingga melahirkan perbedaan persepsi. Selain itu, Pemerintah Daerah terus mendapatkan desakan dari petani agar segera memberikan solusi atas konflik yang berkepanjangan demi keamanan bersama. Oleh karena itu, Pemerintah Daerah terus melakukan desakan kepada Pemerintah Pusat agar segera memberikan keputusan dan solusi yang tepat. Konflik antara petani dengan petani disebabkan adanya perbedaan persepsi, salah satu wakil petani tidak setuju untuk mensertifikatkan tanahnya dikarenakan petani harus patuh dan taat mengikuti pola kerjasama kemitraan dengan PTP XXVII setelah mendapatkan sertifikat tanah. Hal ini dianggap sangat memberatkan dan membebani petani (Badri, 2016: 1).

Konflik tanah Jenggawah terjadi di empat kecamatan dan tujuh desa, yang meliputi Kecamatan Rambipuji Desa Kaliwining, Kecamatan 
Jenggawah Desa Cangkring Baru dan Desa Jenggawah, Kecamatan Ajung Desa Pancakarya, Desa Ajung dan Sukamakmur, serta Kecamatan Mumbul Sari Desa Lengkong. Meskipun areal konflik ini berada di empat Kecamatan, tetapi konflik ini lebih dikenal dengan nama konflik tanah Jenggawah karena persengketaan dan konsolidasi lebih terfokus di Kecamatan Jenggawah Kabupaten Jember.

Ruang lingkup spasial dari tulisan ini adalah batasan yang di dasarkan pada kesatuan wilayah, yaitu di Kecamatan Jenggawah Kabupaten Jember Provinsi Jawa Timur. Dasar pertimbangan ruang lingkup spasial adalah karena konflik yang terjadi di Kecamatan Jenggawah merupakan sebuah konflik nasional yang berkepanjangan. Selain itu, proses gerakan petani Jenggawah mengalami perubahan dari perlawanan fisik menjadi perlawanan simbolik, sehingga sangat menarik untuk mengetahui masalah agraria dan faktor-faktor perubahan gerakan petani Jenggawah tersebut.

Ruang lingkup temporal atau batasan waktu yang digunakan dalam tulisan ini adalah tahun 1998-2005. Dasar pertimbangan lingkup temporal tersebut adalah karena gerakan petani tahun 1998 berbeda dengan tahun-tahun sebelumnya yang identik dengan perlawanan fisik. Perjuangan kali ini dilakukan melalui jalur formal, diplomasi, perundingan-perundingan, dan kooperatif. Tahun 2005 merupakan tahun ketika petani telah mendapatkan hak milik dalam bentuk sertifikat tanah. Pada tahun ini pula petani Jenggawah sudah mulai menggarap lahan pertanian milik mereka dan diakui secara hukum.

Secara spesifik tujuan dari tulisan ini adalah (1) Mengetahui latar belakang munculnya gerakan perjuangan agraria di Jenggawah dan (2) Menjelaskan proses terjadinya perubahan gerakan dari perlawanan fisik menjadi perlawanan simbolik, mendeskripsikan faktor yang mempengaruhi perlawanan simbolik, serta mengungkap legalitas kepemilikan tanah di akhir perlawanan simbolik.

Urgensi kajian ini secara teoritis akan menjadi bagian penting dalam proses penyelesaian konflik agraria di Indonesia. Sebagian besar kajian konflik tanah oleh akademisi lebih terfokus pada konflik yang bersifat fisik atau tindakan kekerasan secara terbuka. Padahal, kajian konflik yang bersifat perundingan dan kooperatif dapat pula menjadi isu penting untuk dikaji lebih dalam dan digunakan sebagai alternatif penyelesaian konflik agraria di Indonesia.

Artikel ini menggunakan metode sejarah kritis yang terdiri dari empat tahapan, yaitu: (a) Heuristis, mencari dan mengumpulkan sumber sejarah, (b) Kritik sumber untuk menguji autentisitas dan kredibilitas sumber, (c) Interpretasi untuk menghubungkan fakta yang satu dengan lainnya, (d) Historiografi atau penulisan kembali peristiwa sejarah (Gotscalk, 1986: 32). Artikel ini menggunakan pendekatan sosiologi politik dengan menekankan teori konflik (Christopher, 1986: 40). Pendekatan sosiologi politik digunakan karena perubahan gerakan perjuangan agraria di Jenggawah tidak terlepas dari permasalahan politik yang bernuansa konflik. Namun, seiring dengan berjalannya waktu, gerakan petani Jenggawah berubah dari perlawanan fisik menjadi perlawanan simbolik pada tahun 1998. Perlawanan simbolik adalah sebuah makna, logika, dan keyakinan yang mengandung bias, tetapi secara halus dan samar dipaksakan kepada pihak lain sebagai sesuatu yang benar. Perlawanan simbolik berupa pemaksaan ide dan gagasan yang dituangkan dalam bentuk teks tertulis agar diakui oleh kelompok lain (Fashri, 2014: 30-32). Pola gerakan petani Jenggawah yang semula dilakukan dengan kekerasan dan perusakan infrastruktur pemerintah kemudian berubah menjadi gerakan nonfisik yang lebih menekankan pada cara-cara perundingan secara kooperatif.

Tulisan ini menggunakan beberapa sumber data, baik yang tergolong sumber primer maupun sekunder. Sumber diperoleh dari kantor Badan Pertanahan Nasional (BPN) Kabupaten Jember mengenai data luas tanah dan jumlah masyarakat yang telah mensertifikatkan tanahnya serta dari Perpustakaan Kantor Pusat Penelitian Kopi dan Kakao Kabupaten Jember berupa foto serpihan gudang-gudang yang terbakar. Selain itu, tulisan ini juga menggunakan arsip-arsip petani yang masih disimpan oleh $\mathrm{H}$. Imam Masyhuri wakil petani Desa Cangkring sebagai salah satu sumbernya. Arsip tersebut berupa Surat Keputusan Menteri Dalam Negeri Direktur Jenderal Agraria No. SK 32/HGB/BA/69 tanggal 15 Desember 1969 dalam rangka pemberian Hak Guna Usaha (HGU) kepada PTPN XXVII selama 25 tahun. Arsip lain yang digunakan sebagai sumber berupa surat Menteri Negara Agraria Kepala Badan Pertanahan Nasional perihal usulan penyelesaian kasus tanah HGU 
PTPN X di Kabupaten Jember pada tanggal 24 Juni 1998. Sumber data primer lain berupa surat kabar yang dimuat di Harian Surya, Memorandum, Radar Jember, serta buku-buku terbitan sejaman dari berbagai karya ilmiah.

\section{Faktor Perubahan Gerakan}

Perlawanan petani Jenggawah terdiri dari dua bentuk, yaitu perlawanan fisik dan perlawanan simbolik. Perlawanan fisik dilakukan untuk menggambarkan perilaku yang terbuka (overt), bersifat menyerang (offensive), yang disertai penggunaan kekuatan secara agresif atau berciri keras dengan cara merusak atau membakar yang menyebabkan kerusakan fisik atau barang orang lain (Fashri, 2014: 30-32). Perlawanan fisik pertama secara terbuka terjadi pada tahun 1979, sedangkan perlawanan fisik kedua berlangsung pada tahun 1994-1995. Seiring dengan berjalannya waktu, pola perlawanan petani Jenggawah mengalami perubahan dari perlawanan fisik menjadi perlawanan simbolik sejak tahun 1998. Perlawanan simbolik petani Jenggawah dilakukan melalui desakan dan paksaan dengan surat pernyataan sikap kepada pemerintah atau lembaga yang terkait mengenai status tanah yang diperjuangkan. Perlawanan simbolik adalah perlawanan tidak tampak dan hanya dikenali dari tujuannya untuk memperoleh pengakuan terhadap kelompok lain. Mekanisme perlawanan simbolik berlangsung secara lembut dan diekspresikan dalam bentuk wacana ilmiah dalam teks tertulis (Fashri, 2014: 141-145).

Perubahan gerakan petani Jenggawah dari perlawanan fisik menjadi perlawanan simbolik secara signifikan disebabkan oleh beberapa faktor. Pertama, faktor eksternal yang terkait dengan pergantian rezim penguasa Orde Baru ke Orde Reformasi. Selama pemerintahan Orde Baru, terdapat fenomena menarik terkait dengan persoalan agraria, yaitu (1) tergesernya status petani, dari petani pemilik tanah menjadi penggarap dan tidak memiliki status sebagai pemilik serta (2) meningkatnya konflik pertanahan yang disertai dengan tindak kekerasan dari unsur aparat keamanan dan keterlibatan unsur birokrasi (Badri, 2016: 69). Kondisi kepemilikan tanah yang tidak dikuasai lagi oleh masyarakat Jenggawah setelah nasionalisasi ini diperparah dengan lahirnya rezim otoriter Orde Baru ketika peta politik pertanahan kian menunjukkan prioritas 'ideologi pembangunan'. Prioritas ini berorientasi kapitalistik, otoritarian, dan represif dengan mengeksploitasi sumber daya alam sehingga mengakibatkan pemerintah Orde Baru secara dominan mengeksploitasi daratan terutama hutan. Model pembangunan Orde Baru sarat dengan utang dan korupsi yang kemudian berdampak terhadap petani Jenggawah. Selama pemerintahan Orde Baru petani dipaksa untuk merusak tanah secara perlahan dengan memberi pupuk kimia, akibatnya tanah petani menjadi gersang dan kurang produktif (Harsutejo, 2010: 220). Kondisi tersebut telah menstimulasi pola gerakan agraria menjadi bercorak tidak terbuka atau di "bawah tanah".

Kedua, faktor eksternal lain terkait dengan surat Boediantoro Asisten Sekretaris Kabupaten Jember, tentang pelepasan Hak Guna Usaha (HGU), yaitu:

(1) Surat pernyataan pelepasan tanah HGU PTPN X Jember seluas 3.117 ha kepada pemerintah untuk diberikan kepada petani menjadi hak milik.

(2) Surat perjanjian kerjasama sistem pola kemitraan antara petani dengan PTPN X Jember (BPN: 1998).

Ketiga, faktor internal, yaitu munculnya kesadaran di kalangan petani yang dipengaruhi oleh pengalaman empirik selama pemerintahan Orde Baru yang seringkali gagal dalam melakukan perlawanan agraria. Petani sebagai pihak yang telah lama menguasai dan mengerjakan tanah, tetapi selama Orde Baru mereka tidak memiliki kekuasaan atas tanah yang mereka kerjakan. Kesadaran tersebut kemudian menjadi sumber motivasi petani untuk melakukan perlawanan dengan cara-cara yang berbeda.

Orde reformasi tahun 1998 tidak hanya membawa perubahan politik, tetapi juga melahirkan perubahan perlawanan petani dalam bentuk ide dan gagasan. Gerakan formal dilakukan mulai dari konsolidasi internal dan eksternal dengan instansi terkait dalam rangka menjalin sebuah hubungan yang harmonis antara petani dengan birokrasi negara tanpa melakukan kekerasan seperti tahun-tahun sebelumnya (Badri, 2016: 64).

\section{Gerakan formal: Vertikal dan Horizontal}

Gerakan formal yang bersifat vertikal maupun horizontal terus dilakukan oleh petani Jenggawah dalam memperjuangkan hak milik atas tanah. Gerakan formal yang bersifat vertikal dilakukan melalui Kepala Dusun, Kepala Desa, 
Camat, Bupati, Gubernur, DPRD, DPR RI, Departemen Dalam Negeri, Dirjen Agraria, Departemen Pertanian, BPN, dan lembaga lain yang terkait. Langkah formal yang bersifat horizontal dilakukan oleh petani melalui Lembaga Bantuan Hukum (LBH) Surabaya, YLBHI Jakarta, Gerakan Mahasiswa Nasional Indonesia (GMNI), dan Pergerakan Mahasiswa Islam Indonesia (PMII) sebagai mitra dialog dan sarana sosialisasi visi dan misi perjuangan petani Jenggawah (Badri, 2016: 64).

Langkah formal dilakukan petani Jenggawah dengan mendesak dan melakukan tuntutan pemberian hak milik melalui pernyataan tertulis kepada instansi terkait. Melalui pernyataan tertulis tersebut, lahir sebuah dialog dan perundingan antara kedua belah pihak untuk mencapai sebuah kesepakatan bersama. H. Imam Masyhuri (wakil petani Desa Cangkring) dan wakil petani lainnya terus mendesak Winarno (Bupati Jember) dengan cara mengirim beberapa surat pernyataan tentang permohonan hak milik atas tanah. Di dalam surat tersebut, petani meminta agar Winarno segera menanggapi surat tuntutan petani tentang pemberian hak milik tanah. Atas desakan petani tersebut, Winarno merespons dengan mengadakan pertemuan di Kantor Pemerintah Daerah Tingkat II Jember pada tanggal 6 Juni 1998.

Menindaklanjuti hasil pertemuan petani Jenggawah dengan pemerintah tentang permohonan hak milik, Winarno kemudian mengirim surat usulan penyelesaian konflik tanah Jenggawah kepada Menteri Negara Agraria atau Kepala BPN, Menteri Pertanian, Menteri Keuangan, Menteri Dalam Negeri, Gubernur Kepala Daerah Tingkat I Jawa Timur, dan Kepala Kantor Pertanahan Kabupaten Jember. Surat tersebut berisi laporan hasil pertemuan antara petani Jenggawah dengan pemerintah dan instansi terkait di Kabupaten Jember pada tanggal 6 Juni 1998. Isi surat tersebut antara lain:

(1) Bahwa hak milik dapat diberikan kepada petani penggarap, dengan syarat PTPN X masih diberi kesempatan untuk mengerjakan lahan tersebut dalam waktu tertentu untuk ditanami tembakau;

(2) Hak milik hanya diberikan kepada petani penggarap, yang betul-betul secara aktif mengerjakan lahan tersebut;

(3) Hak milik tidak boleh diperjualbelikan kepada pihak-pihak lain yang bertempat tinggal di luar desa tersebut;
(4) Pemilik harus memberi kesempatan kerja kepada para petani atau buruh tani yang telah mempunyai hak milik atau hak garap;

(5) Pemilik harus mentaati dan memenuhi kewajiban-kewajiban di atas.

Berkaitan dengan pokok permasalahan di atas, apabila kepemilikan tanah HGU PTPN X diserahkan kepada petani penggarap, mereka akan melaksanakan dan harus sanggup mentaati segala ketentuan yang telah disepakati bersama. Winarno mendesak Kepala BPN agar mempertimbangkan permohonan petani Jenggawah atas tanah yang selama ini digarap dan secara $d e$ facto dikuasainya (Winarno, Bupati Jember: 1998).

Menanggapi surat Winarno dan surat $\mathrm{H}$. Imam Masyhuri dan kawan-kawan tanggal 15 Juni 1998 perihal usulan penyelesaian konflik tanah Jenggawah, Basri Durin (Kepala BPN Jakarta) menjawab surat Bupati Kepala Daerah Tingkat II Jember nomor 590/904/436.010/1998 pada tanggal 8 Juni 1998. Ia menanggapi desakan petani tentang permohonan hak milik atas tanah HGU PTPN X Jember dan berjanji akan menjamin kepentingan petani maupun PTPN X, karena permasalahan ini telah berkembang lebih dari dua dasawarsa sehingga di era reformasi perlu segera mendapatkan prioritas penyelesaian.

Berdasarkan pertimbangan Basri Durin, tidak mungkin bagi PTPN X untuk kembali menanam tembakau. Agar konflik tanah tidak berkepanjangan, ia berpendapat:

(1) Kepada petani yang bersangkutan diberikan hak milik atas tanah yang dimaksud, dalam pemberian hak itu ditegaskan kewajibankewajiban petani untuk menyediakan tanah bagi PTPN X untuk menanam tembakau;

(2) Melarang petani untuk menanam tanaman yang berpengaruh negatif terhadap tanaman tembakau dan lain-lain.

Berdasarkan penjelasan dan pendapat Basri Durin di atas, Winarno menganggap BPN Jakarta kurang serius dalam menyelesaikan konflik tanah Jenggawah. Sebab, Basri Durin hanya menjelaskan kronologis pemberian HGU dan dinamika konflik yang terjadi, tetapi tidak segera memberikan solusi atas masalah sengketa tanah yang di alami petani Jenggawah.

Desakan melalui surat tertulis terus dilakukan oleh Winarno kepada instansi terkait mengenai usulan penyelesaian konflik tanah 
Jenggawah. Surat Winarno kemudian ditanggapi oleh Basri Durin. Isi surat Basri Durin menginformasikan hasil pertemuan dan memperoleh 2 kesimpulan, yaitu:

(1) Secara prinsip usulan masyarakat penggarap disetujui;

(2) Sebelum hak milik diberikan kepada petani penggarap, terlebih dahulu dibuat perjanjian antara calon penerima hak milik (petani) dengan PTPN X khususnya yang berkaitan dengan persyaratan pemberian hak milik dan jaminan kelangsungan tanaman tembakau bagi PTPN X. Menteri Negara Agraria meminta kepada Kepala kantor Wilayah BPN Provinsi Jawa Timur di Surabaya agar mengupayakan dan mengkoordinasikan pembuatan perjanjian dan selanjutnya melaporkan hasilnya (BPN: 1998).

Upaya penyelesaian konflik tanah Jenggawah terus dilakukan dengan mengadakan pertemuan di ruang Binaloka Kantor Gubernur Jawa Timur pada tanggal 12 Agustus 1998. Momentum yang sangat bersejarah bagi petani Jenggawah adalah ketika Boediantoro (asisten I Sekwilda Jember) membacakan dua poin tentang persoalan yang menjadi inti kasus tanah Jenggawah pada tanggal 1 Oktober 1998. Dua poin tentang pelepasan HGU tersebut adalah sebagai berikut.

(1) Surat pernyataan pelepasan tanah Hak Guna Usaha (HGU) PTPN X Jember seluas 3.117 ha kepada pemerintah untuk diberikan kepada petani menjadi hak milik;

(2) Surat perjanjian kerjasama sistem pola kemitraan antara petani dengan PTPN X Jember (BPN: 1998).

Setelah dua poin di atas dibacakan, kemudian dilakukan penandatanganan bersama antara pihak PTPN $X$ dan wakil petani Jenggawah. Pelepasan tanah secara resmi juga dilakukan oleh Mas Darwito (Direktur Sumber Daya Manusia dan Sosial PTPN X) mewakili Dirut berdasarkan surat kuasa khusus yang telah diberikan, kemudian dilanjutkan dengan penandatanganan oleh 14 tokoh wakil petani Jenggawah (Hafid, 2001: 145-146).

Kesepakatan antara petani Jenggawah (penerima hak milik) dengan PTPN X tercapai pada tanggal 1 Oktober 1998 atas surat perjanjian berdasarkan pola kerjasama kemitraan yang terdiri dari 8 (delapan) bab dan mempunyai 9 (sembilan) butir pasal. Sistem kemitraan tersebut merupakan pengikat setiap penerima hak milik. Setiap penerima hak milik sebagai akibat dari perbuatan hukum peralihan hak juga wajib terikat dengan perjanjian kerjasama tersebut, terutama yang berkaitan dengan penyediaan tanah kepada PTPN X untuk ditanami tembakau sesuai dengan isi perjanjian pola kerjasama kemitraan (Surat Perjanjian Kerjasama Berdasarkan Pola Kemitraan, 1998: 1-3). Konsep pola kerjasama kemitraan diusulkan oleh Kanwil BPN Jawa Timur, bukan usulan dari petani penggarap atau PTPN X.

Menanggapi konsep pola kerjasama kemitraan, H. Imam Chodlori (wakil petani Desa Cangkring) berpendapat bahwa seharusnya pola kerjasama kemitraan diusulkan oleh kedua belah pihak yang berkonflik, yaitu petani penggarap dan PTPN X. Namun, usulan tersebut malah diusulkan oleh Sunar (Kanwil BPN Jawa Timur). Usulan tersebut menjadi pertanyaan besar bagi petani Jenggawah karena usulan selalu datang dari pihak pemerintah bukan dari petani atau PTPN X, sedangkan yang akan menjalankan teknis dari pola kerjasama kemitraan adalah petani penggarap dengan PTPN X (Badri, 2016: 78-79). Petani Jenggawah menganggap pola kerjasama kemitraan hanyalah langkah awal diperolehnya hak milik. Hal yang sangat penting bagi petani adalah diperolehnya hak milik atas tanah yang mereka perjuangkan selama bertahun-tahun, serta tidak ada lagi perlakuan diskriminatif dan intimidatif.

Bagi petani, pola kerjasama kemitraan tidak dapat dijalankan begitu saja. Hal yang terpenting adalah memprioritaskan kejelasan pemberian hak milik atau sertifikat tanah kepada petani. Setelah pemberian sertifikat hak milik selesai, baru melaksanakan pola kerjasama kemitraan. Hal tersebut dilakukan untuk menghindari terjadinya manipulasi kasus tanah Jenggawah menjadi tidak jelas posisinya. Namun pada kenyataannya, petani penggarap lebih senang menggarap tanahnya sendiri dengan menghiraukan pola kerjasama kemitraan (Badri, 2016: 79). Terbukti setelah dilakukan pelepasan tanah dan pemberian sertifikat hak milik pada tahun 2001 kepada petani Jenggawah, pola kerjasama kemitraan tersebut belum pernah dilaksanakan.

Belum terlaksananya pola kerjasama kemitraan, menurut Slamet Junaedi (Kepala Kantor Pertanahan BPN Jember), disebabkan proses pemberian sertifikat hak milik kepada 
petani Jenggawah yang masih belum terealisasi sepenuhnya. BPN Kabupaten Jember masih mengupayakan penyelesaian proses pemberian sertifikat hak milik atas tanah kepada para petani. Setelah pemberian sertifikat hak milik selesai diberikan kepada seluruh petani penggarap yang terlibat konflik tanah Jenggawah, maka pola kerjasama kemitraan akan dilaksanakan sesuai dengan isi perjanjian yang telah disepakati oleh petani Jenggawah dan PTPN X (Badri, 2016: 80). Jika kerjasama kemitraan telah dilaksanakan tetapi dalam perjalanan terjadi perselisihan antara kedua belah pihak mengenai perjanjian ini, baik dalam penafsiran maupun pelaksanaan yang tidak dapat diselesaikan di antara kedua belah pihak secara musyawarah, perselisihan akan diselesaikan dalam Badan Peradilan Umum di Kabupaten Jember (Surat Perjanjian Kerjasama Berdasarkan Pola Kemitraan, 1998: 12). Indikasi yang menghambat forum musyawarah kemitraan dikarenakan forum ini bukan diusulkan langsung oleh pihak PTPN $X$ ataupun petani penggarap. Forum musyawarah kemitraan tersebut diusulkan oleh Sunar (Kanwil BPN Jawa Timur). Dari usulan tersebut, petani Jenggawah masih bersedia bekerjasama dengan PTPN $\mathrm{X}$ meskipun merupakan lawan, asalkan hak-hak petani dipenuhi sesuai dengan undang-undang yang berlaku dan adanya konsistensi serta kejujuran yang harus dipatuhi jika kerja sama kemitraan benar-benar dilaksanakan (Badri, 2016: 81).

\section{Dinamika Sertifikasi Tanah Jenggawah}

Proses perjuangan sertifikat dilakukan oleh petani setelah turunnya surat pelepasan tanah HGU oleh Darwito (Direktur Sumber Daya Manusia dan Umum) PTPN X, yang dilanjutkan dengan surat pernyataan Basri Durin, yang memutuskan untuk membatalkan HGU atas tanah perkebunan Ajunggayasan Jenggawah yang terletak di Kabupaten Jember. Namun, proses pengesahan hak milik atau sertifikasi tidak berjalan dengan lancar sesuai yang diharapkan petani. Tindakan intimidasi, kekerasan, dan perusakan kembali dilakukan oleh orang-orang yang kurang setuju dengan tuntutan petani penggarap (Badri, 2016: 82). Hambatan dalam proses penuntasan sertifikat hak milik atas tanah kepada petani masih selalu terjadi meskipun kesepakatan telah dicapai oleh kedua belah pihak. Hambatan ini muncul terutama dari pendukung dan karyawan PTPN X, seperti buruh tani dan mandor. Buruh tani adalah buruh yang bekerja di perkebunan milik PTPN X sebagai tenaga kerja harian. Oleh karena itu, mereka selalu menjadi musuh petani Jenggawah (Nurhasim, 1997: 90).

Pada awal proses perjuangan sertifikat hak milik di tahun 1999 tercatat beberapa tindakan kekerasan dan perusakan yang terjadi. Peristiwa pertama terjadi di rumah $\mathrm{H}$. Imam Mashuri (wakil petani Desa Cangkring) pada bulan Januari 1999. Salah satu oknum PTPN X mengancam akan membakar rumah wakil petani; ancaman tersebut seolah-olah mengingatkan kepada peristiwa tahun 1979. Selain itu, beberapa karyawan PTPN X yang diketuai oleh Abdul Bari (Asisten Sinder atau pengawas) mengumpulkan tanda tangan yang kemudian hasil tanda tangan tersebut dikirim kepada $\mathrm{M}$. Rofik Azmy (Camat Jenggawah) pada tanggal 13 Januari 1999. Isi surat tersebut menuntut agar perjuangan petani Jenggawah dalam memperjuangkan sertifikat dihentikan karena dianggap mengganggu situasi dan stabilitas masyarakat sekitar. Surat tersebut langsung direspon oleh M. Rofik Azmy dengan memanggil perwakilan petani untuk mengklarifikasi surat pernyataan asisten Sinder tersebut (Badri, 2016: 83).

Saat proses klarifikasi, wakil petani Jenggawah membantah surat tersebut dan mengatakan bahwa dalam perjuangan sertifikat hak milik situasi masyarakat masih tetap stabil. Proses inventarisasi pun berjalan dengan lancar tanpa mengganggu hak-hak orang lain dan tidak ada suatu permasalahan yang muncul. Wakil Petani menganggap sebaliknya, bahwa yang mengganggu situasi dan stabilitas masyarakat sekitar adalah kelompok-kelompok PTPN X yang tidak rela tanahnya diberikan hak milik kepada petani penggarap (Badri, 2016: 84).

Meskipun kesepakatan telah tercapai antara petani dan PTPN X, tetapi masih banyak hambatan dalam proses penuntasan sertifikat hak milik. Terbukti beberapa karyawan PTPN X masih belum rela melepaskan tanah untuk dijadikan hak milik kepada petani Jenggawah. Tindakan perusakan oleh Karyawan PTPN X tersebut merupakan bentuk pelawanan mereka kepada petani penggarap yang akan diberi hak milik. Konflik yang terjadi di atas disebabkan karena karyawan PTPN X sangat tergantung kepada perusahaan. Konflik tanah Jenggawah merupakan dualisme kelompok kepentingan yang saling bertentangan. Namun, petani Jenggawah tidak terpancing emosinya atas 
kejadian tersebut. Kekerasan yang dilakukan ditanggapi dengan lapang dada dan tidak membalas dengan kekerasan. Proses sertifikasi tanah terus berjalan dengan dukungan penuh dari pihak BPN Kabupaten Jember, mulai dari proses pengukuran, inventarisasi, sampai diterbitkannya SKPT (Surat Keterangan Pendaftaran Tanah) (Badri, 2016: 86).

\section{Proses Inventarisasi Tanah Jenggawah}

Berdasarkan penetapan biaya inventarisasi subjek dan objek, BPN Kabupaten Jember mengirim surat pemberitahuan kepada Camat Rambipuji, Camat Ajung, Camat Jenggawah, dan Camat Mumbulsari agar segera melakukan proses inventarisasi, pengukuran tanah, dan penyuluhan sesuai dengan hasil rapat anggota tim inventarisasi. Ada empat (4) poin hasil rapat tim inventarisasi, yaitu sebagai berikut.

(1) Inventarisasi yang dilaksanakan adalah inventarisasi para petani penggarap tanah yang secara nyata mengerjakan tanahnya;

(2) Data inventarisasi dan pengukuran yang dihasilkan merupakan data yang dihasilkan oleh petugas lapangan dan dibenarkan oleh Kepala Desa serta wakil petani setempat;

(3) Data hasil inventarisasi dan pengukuran yang tersebut pada angka 2 (dua) di atas diumumkan di desa setempat;

(4) Keberatan-keberatan yang ada hubungannya dengan hasil inventarisasi dan pengukuran yang diumumkan pada angka 3 di atas dapat diajukan kepada tim inventarisasi (BPN Jember: 1999).

Sesuai dengan SK Bupati Tingkat II Jember Nomor 90/1998, sebagian wakil petani Jenggawah dimasukkan sebagai anggota tim inventarisasi tanah. Hal ini bertujuan agar wakil petani mengetahui dan mengawal proses inventarisasi tanah agar berjalan lancar. Sebelumnya wakil petani tidak menduga jika akan dimasukkan dalam tim inventarisasi oleh BPN Kabupaten Jember. Selain mengawal proses inventarisasi, wakil petani juga bertugas untuk melakukan musyawarah dan menyampaikan biaya inventarisasi dan pengukuran tanah kepada petani penggarap serta menyampaikan semua hasil rapat tim inventarisasi tanah yang akan melaksanakan pengukuran tanah.

Bidang-bidang tanah yang akan di inventarisasi meliputi Desa Kaliwining sebanyak 1.493 bidang tanah, Kecamatan Ajung sebanyak 1.172 bidang tanah, meliputi Desa Pancakarya
734 bidang tanah, Desa Sukamakmur sebanyak 901 bidang, Kecamatan Jenggawah sebanyak 1.918 bidang, dan Desa Lengkong sebanyak 1.174 bidang tanah (BPN Jember: 1999).

\section{Ending Gerakan: Distribusi Tanah dan Penguasaan secara De facto dan De jure}

Sesuai dengan surat keputusan Bupati Kepala Daerah Tingkat II Jember nomor 20-101988 tentang tim inventarisasi dan pemberian hak milik atas tanah kepada petani penggarap serta berdasarkan berita acara sidang panitia pertimbangan landreform nomor 02/BA.PPL/2000 tanggal 22 September 2000, BPN memberikan hak milik kepada saudara Teguh Samsul Arifin dan kawan-kawan sebanyak 20 (dua puluh) orang yang meliputi 25 (dua puluh lima) bidang, masing-masing merupakan tanah pertanian seluas $62.515 \mathrm{~m}^{2}$ yang merupakan tanah negara bekas HGU nomor 2 Desa Jenggawah dengan luas seluruhnya 554,2.714 ha dan HGU nomor 2 Desa Cangkring dengan luas 191, 1.100 ha dengan letak, luas, nomor kode, petak, serta batas-batas sesuai dengan peta bidang tanah nama yang bersangkutan (BPN Jember: 2001).

Surat keputusan pemberian hak atas tanah kepada petani penggarap berupa sertifikat yang diterbitkan oleh BPN Jember pada tahun 2001 berfungsi sebagai dasar atau hak pengakuan negara terhadap seseorang mengenai hak atas tanah yang berasal dari negara dengan memenuhi persyaratan dan kewajiban yang telah disepakati bersama agar memperoleh tanda bukti kepemilikan tanah. Dsengan diserahkannya sertifikat tersebut membuat petani merasa senang karena perjuangan mereka telah berakhir dan apa yang mereka perjuangkan telah tercapai. Hal ini karena dalam perjuangan tanah maupun sertifikat tersebut banyak biaya yang harus mereka keluarkan, baik biaya dalam proses perjuangan maupun proses inventarisasi (Badri, 2016: 98).

Namun setelah terbitnya sertifikat tanah, petani penggarap mendapatkan perlakuan manipulatif, karena di dalam isi sertifikat tanah terdapat pembebanan hak yang menyatakan bahwa "Berdasarkan Surat Keputusan Kepala Kantor Pertanahan Kabupaten Jember Tanggal 08-02-2001 Nomor 02-420.335.34-2001 tanah yang di berikan dilarang dialihkan kepada pihak lain baik sebagian atau seluruhnya kecuali diperoleh izin dari Kepala Kantor Pertanahan Kabupaten Jember“ (Sertifikat Hj. Siti Qomariah: 2001). Meskipun petani telah mendapatkan 
sertifikat tanah yang di keluarkan oleh BPN Kabupaten Jember, tetapi karena adanya pembebanan hak, petani tidak mendapatkan hak sepenuhnya. Petani Jenggawah mulai terusik dan anggapan bahwa sertifikat tanah adalah palsu semakin menyebar luas dan menjadi masalah baru yang harus dihadapi. Wakil petani Jenggawah di masing-masing desa merespons masalah tersebut dengan mengirim surat kepada BPN Jember tentang maksud dan tujuan pembebanan hak tersebut pada tanggal 4 Februari 2002 (Badri, 2016: 99). Surat wakil petani segera ditanggapi oleh BPN Kabupaten Jember melalui surat Nomor 410.353.4-476 perihal penjelasan hak milik atas tanah pertanian pada tanggal 15 Februari 2002.

Alasan BPN Kabupaten Jember memberikan sertifikat dengan pembebanan hak terkait dengan kewenangan pemerintah untuk mengatur penggunaan, penguasaan, dan kepemilikan hak atas tanah berdasarkan Pasal 7 junto Pasal 17 UUPA nomor 5 tahun 1960 (UUPA No. 5, 1960: 9) yang pelaksanaannya diatur dalam Undang-Undang Nomor 56 PRP Tahun 1960 tentang penetapan luas tanah pertanian. Setiap petani atau badan hukum yang mempunyai suatu hak atas tanah pertanian pada azasnya diwajibkan mengerjakan atau mengusahakannya sendiri secara aktif dengan mencegah cara-cara pemerasan pasal 10 ayat 1 UUPA (UUPA No. 5, 1960: 6). Ketentuan ini dimaksudkan agar tanah yang telah diberikan kepada petani Jenggawah dikerjakan secara aktif. Hal itu diatur dalam Peraturan Pemerintah Nomor 224 Tahun 1961 JIS. Selain tiu, hal itu juga diatur dalam Peraturan Pemerintah Nomor 41 Tahun 1964 dan Peraturan Pemerintah Nomor 4 Tahun 1977 yang terkait dengan larangan dan pemilikan tanah secara absente (guntai), yang isinya menyatakan bahwa pemilik tanah pertanian yang bertempat tinggal di luar kecamatan atau desa letak tanahnya (BPN Jember, 2002: 1).

Ketentuan ini dimaksudkan untuk mengadakan perlindungan bagi petani lemah. Salah satu bentuk pengawasan atau pengendalian dalam perbuatan hukum yang dimaksud untuk memindahkan hak milik tersebut di atas melalui izin peralihan hak yang diatur dalam:

(1) Peraturan Menteri Agraria Nomor 14 Tahun 1961 tentang permintaan dan pemberian izin pemindahan hak atas tanah dan Peraturan Dirjen Agraria nomor 4 tahun 1968 tentang penyelenggaraan izin pemindahan hak atas tanah.

(2) Peraturan Menteri Dalam Negeri Nomor SK 59/DDA/1970 tentang penyederhanaan peraturan perjanjian pemindahan hak atas tanah. Dalam peraturan ini izin pemindahan hak diperlukan untuk salah satunya pemindahan hak milik atas tanah pertanian.

Pemindahan hak milik atas tanah yang tercantum di dalam sertifikat adalah tanda yang menyatakan bahwa hak tersebut hanya boleh dipindahtangankan apabila telah diperoleh izin dari instansi yang berwenang. Hal itu sesuai dengan peraturan Menteri Negara Agraria atau Kepala BPN Nomor 3 Tahun 1997 pasal 98 ayat 1 huruf (a) jo. Pasal 46 Peraturan Pemerintah 24 Tahun 1997 (BPN, 2002: 2).

Dalam mengatasi kontroversi tentang pencantuman pembebanan hak dalam isi sertifikat, Lembaga Bantuan Hukum (LBH) Surabaya, atas nama warga Jenggawah, menyatakan adanya keganjilan. Kontroversi itu muncul seiring terbitnya sertifikat hak milik atas tanah yang diikuti dengan pembebanan hak yang dilakukan oleh kantor BPN Kabupaten Jember kepada warga Desa Cangkring Kecamatan Jenggawah. Isi dari ketentuan yang terdapat dalam sertifikat hak milik dan pembebanan hak dinilai sangat merugikan petani karena ada larangan untuk mengalihkan haknya kepada orang lain.

Ketentuan itu jelas menyimpang dari Undang-Undang Nomor 5 Tahun 1960 UUPA Pasal 20 ayat (1) dan (2) (UUPA No. 5, 1960: 10) yang menyatakan bahwa hak milik merupakan hak tertinggi dan pemegangnya berhak mengalihkan kepada siapapun. Pemaksaan bagi pemegang hak milik untuk selalu menyewakan tanahnya kepada PTPN X jelas tidak sesuai dengan UUPA 1960. Selain itu, terdapat pula pemaksaan kepada petani mengenai komoditi pertanian yang harus ditanam, yaitu tembakau (LBH Surabaya, 2003: 1).

Atas dasar tersebut, LBH Surabaya bersama petani Jenggawah menyatakan surat izin pembebanan hak atas tanah yang dikeluarkan dan ditandatangani oleh kantor BPN bertentangan dengan UUPA dan Undang-Undang Nomor 4 Tahun 1996 sehingga keputusan BPN dan pencantuman syarat dalam sertifikat hak milik atas tanah batal demi hukum. Oleh karena itu, petani Jenggawah yang mendapatkan surat izin pembebanan hak atas tanah tidak perlu 
mematuhi atau melaksanakan isi dari surat tersebut karena tidak mempunyai kekuatan yang mengikat. Selain itu, terdapat kesalahan fatal dari BPN dalam melaksanakan tugasnya sebagai instansi yang mengatur masalah pertanahan. Oleh karena itu, BPN harus segera mempertanggungjawabkan secara hukum kesalahan yang telah diperbuat dengan mencabut SK tentang pemberian izin pembebanan hak atas tanah dan menghapus isi pencantuman syarat dalam sertifikat (LBH Surabaya, 2003: 2).
Proses sertifikasi terus dilakukan meskipun tercantum pembebanan hak dalam isi sertifikat. Petani Jenggawah yang belum mengurus sertifikat terus melakukan upaya pendaftaran tanah melalui wakil petani di masing-masing desa pada tahun 2004-2005. Setelah petani melakukan pendaftaran tanah dan proses inventarisasi, jumlah redistribusi dan penetapan hak milik atas tanah bekas HGU PTPN X di 7 (tujuh) desa dan 4 (empat) kecamatan selama periode tahun 2001-2005 dapat dilihat pada tabel 1 di bawah ini.

Tabel 1.

Jumlah Redistribusi Tanah dan Penetapan Hak Milik

\begin{tabular}{|c|c|c|c|c|c|}
\hline No & Desa & Tahun & Luas $\left(\mathrm{m}^{2}\right)$ & Bidang & KK \\
\hline 1 & Kaliwining & $2001-2005$ & $2,196,404$ & 875 & 871 \\
\hline 2 & Ajung & $2001-2005$ & 806,391 & 231 & 184 \\
\hline 3 & Pancakarya & $2001-2005$ & 407,584 & 185 & 170 \\
\hline 4 & Sukamakmur & 2001-2005 & 412,769 & 187 & 172 \\
\hline 5 & Jenggawah & 2001-2005 & $1,114,747$ & 498 & 412 \\
\hline 6 & Lengkong & $2001-2005$ & 193,335 & 74 & 64 \\
\hline 7 & Cangkring & $2001-2005$ & 370,828 & 160 & 145 \\
\hline \multicolumn{2}{|r|}{ Jumlah } & $2001-2005$ & $5,502,058$ & 2210 & 2018 \\
\hline
\end{tabular}

Sumber: Diolah dari Surat Kantor BPN Jember, tentang legalisasi aset tanah Objek Land reform bekas HGU Kebun Ajunggayasan PTPN X Jember pada tanggal 18 Februari 2013.

Jika dilihat dari tabel di atas, redistribusi tanah bekas HGU PTPN X Kebun Ajunggayasan Jember yang telah diterbitkan sertifikat tanahnya oleh pemerintah dan diberikan kepada petani Jenggawah selama periode tahun 2001-2005 berjumlah 2.210 bidang dan telah diberikan kepada 2.018 kepala keluarga (KK) (Badri, 2016: 108). Jumlah tersebut merupakan bukti berhasilnya perjuangan petani Jenggawah dalam memperjuangkan sertifikat selama tahun 19982005. Selama kurun waktu tersebut, sebagian petani Jenggawah telah menguasai tanah secara de facto dan de jure. Pendaftaran tanah dan pemberian sertifikat oleh BPN Jember kepada petani Jenggawah terus dilakukan. Sejak tahun 2001-2012 pemberian sertifikat tanah mencapai 6.424 bidang dan telah diberikan kepada 5.398 kepala keluarga (KK). Data tersebut menunjukkan bahwa pemberian sertifikat tanah Jenggawah telah mencapai 90\% (BPN Jember: 2013).

Namun, ada salah satu desa yang terlibat dalam konflik tanah Jenggawah yang enggan melakukan proses legalisasi tanah. Joko Tarup, salah satu wakil petani Desa Sukamakmur masih enggan mengurus legalitas tanah yang dimiliki, karena menganggap isi sertifikat tentang pembebanan hak masih sangat memberatkan rakyat dan penuh dengan rekayasa karena masih ada syarat yang mengikat. Joko Tarup mengatakan jika petani mengurus sertifikat sama halnya dengan bunuh diri karena proses legalisasi hak milik sifatnya hanya meredam emosi masyarakat. Petani Jenggawah terus berpacu dengan waktu untuk memperjuangkan tanah, sedangkan opini di media massa mengabarkan kemenangan para petani, tetapi pada realitasnya mereka masih terombangambing dalam ketidakpastian legal formal atas tanah yang mereka kuasai (Badri, 2016: 109).

\section{Penutup}

Perlawanan simbolik petani Jenggawah dalam melakukan penuntutan hak dan pengakuan kepemilikan tanah kepada pemerintah dilakukan secara halus dalam bentuk surat pernyataan sikap yang tertuang dalam teks tertulis. Perubahan gerakan petani Jenggawah dari perlawanan fisik menjadi perlawanan simbolik disebabkan oleh beberapa faktor. Pertama, faktor eksternal yang terkait dengan pergantian pemerintahan Orde Baru ke Orde Reformasi. Bias dari perubahan politik nasional melahirkan perubahan gerakan petani Jenggawah yang tertuang dalam tataran ide, gagasan, dan musyawarah. Gerakan tersebut dilaksanakan tanpa melakukan perlawanan fisik seperti yang terjadi tahun-tahun sebelumnya. 
Kedua, faktor eksternal yaitu melepas dan membatalkan HGU untuk diberikan kepada petani. Sesuai dengan surat Boediantoro (Asisten Sekretaris Kabupaten Jember) tentang pelepasan Hak Guna Usaha (HGU) atas tanah yang akan diberikan hak milik kepada petani Jenggawah. Ketiga, faktor internal yaitu munculnya kesadaran di kalangan petani yang dipengaruhi oleh pengalaman empirik selama pemerintahan Orde Baru yang seringkali gagal dalam melakukan perlawanan agraria. Kesadaran tersebut menjadi sumber motivasi petani untuk melakukan perlawanan dengan cara-cara yang berbeda.

Legalitas pemilikan tanah di akhir perlawanan simbolik ditandai dengan pemberian sertifikat tanah kepada petani Jenggawah oleh BPN Jember secara bertahap. Awal pemberian sertifikat tanah kepada petani sebanyak 25 sertifikat pada tahun 2001. Jumlah pemberian sertifikat pada tahun 2001-2005 telah mencapai 2.210 bidang dan 2.018 sertifikat. Pemberian tanah secara de facto dan de jure kepada petani masih menyisakan polemik karena di dalam sertifikat tertulis pembebanan hak. Pembebanan hak tersebut berupa larangan mengalihkan tanah kepada pihak lain baik sebagian atau seluruhnya kecuali mendapat izin dari BPN Jember. Oleh karena itu petani merasa tidak mendapatkan hak penuh atas tanah karena terdapat pencantuman pembebanan hak dalam sertifikat.

\section{Daftar Pustaka}

\section{Buku}

Christopher, Loyd. (1986). Teori Sosial dan Praktek Politik, (terj) Nazaruddin Syamsudin. Jakarta: CV. Rajawali.

Il Badri, Mohamad. (2016). Gerakan Perjuangan Agraria di Kecamatan Jenggawah Kabupaten Jember Suatu Bentuk Perlawanan Simbolik. Tesis Universitas Diponegoro Semarang.

Hafid, Joko S. (2001). Perlawanan Petani Kasus Tanah Jenggawah. Jakarta: Latin.

Harsutejo. (2010). Kamus Kejahatan Orba Cinta Tanah Air dan Bangsa. Jakarta: Komunitas bamboo.

Setiawan, Usep. (2010). Kembali ke Agraria. Yogyakarta: STPN Press.

Fashri, Fauzi. (2014). Menyingkap Kuasa Simbol Pierre Bourdieu. Yogyakarta: Jalasutra.
Gotscalk, Louis. (1986). Mengerti sejarah (terj). Nugroho Noto Susanto. Jakarta: YPUI.

Wiradi, Gunawan. (2000). Reforma Agraria Perjalanan yang Belum Berakhir. Yogyakarta: Insist.

Ya'cub, Achmad. (2007). Konflik Agraria, Tinjauan Umum Kasus Agraria di Indonesia. Jakarta: Federasi Serikat Petani Indonesi.

\section{Undang-Undang}

Pasal 17 Undang-Undang No. 5 Tahun 1960 Tentang Peraturan Dasar Pokok-pokok Agraria.

Pasal 10 ayat 1 Undang Undang No. 5 Tahun 1960 Tentang Peraturan Dasar Pokokpokok Agraria.

Pasal 20 Undang Undang No. 5 Tahun 1960 Tentang Peraturan Dasar Pokok-pokok Agraria.

\section{Arsip / Dokumen}

Akta notaris Harun Kamil, SH. Nomor 43 tanggal 11 Maret 1996.

Surat Keputusan Menteri Dalam Negeri Direktur Jenderal Agraria nomor SK 32/HGB/BA/69. Tanggal 15 Desember 1969.

Surat Perjanjian Kerjasama Berdasarkan Pola Kemitraan PT. Perkebunan Nusantara X (Persero) Berkedudukan di Surabaya dengan Penerima Hak Milik atas Tanah Perkebunan Ajunggayasan Jenggawah Jember, 1 Oktober 1998.

Surat Menteri Negara Agraria Kepala Badan Pertanahan Nasional, perihal usulan penyelesaian kasus tanah HGU PTPN X Jember, nomor 570.35-1995, Jakarta 24 Juni 1998.

Surat Winarno (Bupati Kepala Daerah Tingkat II Jember) Kepada Menteri Negara Agraria atau Kepala Badan Pertanahan Nasional, nomor 590/904/436.010/1998. Tanggal 8 Juni 1998.

Surat (Hasan Basri Durin) Menteri Negara Agraria atau Kepala Badan Pertanahan Nasional, Nomor 540.1-334, Jakarta 20 Juli 1998. 
Surat Badan Pertanahan Nasional Kantor Pertanahan Kabupaten Jember Nomor 410.353.4-1405. Tanggal 20 Maret 1999.

Surat Darwito (Badan Pertanahan Nasional atau Kepala Kantor Pertanahan Kabupaten Jember), tanggal 5 Januari 2001.

Surat Tjahyo Arianto, (Kepala Kantor Badan Pertanahan Nasional Kantor Pertanahan Kabupaten Jember), nomor 410.353.4476, Tentang Penjelasan Sertifikat Hak Milik Atas Tanah Pertanian, bulan Pebruari 2002.

Surat Andi Hermawan, Devisi Tanah dan Petani (Lembaga Bantuan Hukum Surabaya Jawa Timur), perihal surat pernyataan, nomor 03/SK/LBH/I//2003. Surabaya 19 Pebruari 2003.
Surat Legalisasi Asset Tanah Objek Landreform BPN Jember, 8 Pebruari 2013. Sertifikat $\mathrm{Hj}$. Siti Qomariah.

\section{Artikel}

Nurhasim, "Konflik Tanah di Jenggawah, Tipologi dan Pola Penyelesaiannya" (Prisma 7, 1997).

Syafi'i, Imam. (2016). Konflik Agraria di Indonesia: Catatan Reflektif Konflik Perkebunan Sawit di Kota Waringin Timur. Jurnal Masyarakat \& Budaya, Volume 18 No. 3.

Harian Surya, 16 September 1994.

Sengketa Agraria (Mata Najwa, Metro TV, 2010). 